\title{
CLICKERS ARE DYNAMIC ASSESSMENT TOOLS IN MARKETING EDUCATION
}

\author{
Pelin Bicen, Penn State University, Erie, USA \\ Mary Beth Pinto, Penn State University, Erie, USA
}

\section{INTRODUCTION}

The main objective of this study is to introduce clickers (personal response system, PRS) as a dynamic assessment tool, and investigate the effect of clicker technology, as an effective intervention, on students' behaviors and motivation. Further, this study aims to offer a rationale for using clicker technology and suggest best practices for integrating the technology into marketing course curriculums. For that purpose, we will test the effectiveness of clicker technology in a study with undergraduate students using a one group pretest-posttest quasi experimental design. The study will measure, in general, the effect of clicker technology on students' intrinsic motivation, self-regulated learning strategies, perceived autonomy, perceived competence, and task-mastery orientation.

\section{THEORETICAL BACKGROUND}

Time changes so quickly. It certainly could be used to characterize current marketing practices. Today's marketing problems require marketing professionals to be equipped with critical thinking abilities and creative skills that will allow them to have an innovative and solution-centered approach. Amid this firestorm of change, old methods and long-held assumptions in marketing education will no longer apply; therefore, marketing education is at a defining point in its history. Several questions arise: (1) What are our responsibilities as marketing scholars when we prepare them to constantly changing marketing environment? and (2) How can we provide their assurance of learning?

One way to assure student learning is assessment. In today's business education, the primary focus of assessment is not simply what students learn but rather the knowledge and creative skills that they possess. As a testimony to this statement, one of the standards that AASCB, the premier accrediting agency for collegiate business programs, requires business programs to meet is to link learning objectives with learning outcomes through effective assessment tools. AASCB demands business programs to adopt the assessment for learning approach rather than the assessment of learning approach. Indeed, one-third of the AASCB standards are assessment-related requiring assessment to be part of the learning process rather than an outcome itself. This is a paradigm shift in business education. Briefly, we argue that effective assessment tools should measure not only what students learn, but also their propensity to learn. Therefore, drawing from the Dynamic Assessment Theory (Feurstein 1990; Vygotsky 1978), we propose that clickers can be used as dynamic assessment tools in marketing education.

\section{CONCLUSIONS AND IMPLICATIONS}

This study is an ongoing research project. Therefore, we propose that clickers will fit into the new learning paradigm (e.g., assessment for learning) and transform both the marketing educators' and students' approach to assessment. With an instant critical feedback, clickers inform marketing scholars about not only what students learn but also how they learn and their propensity to learn. Further, as a dynamic assessment tool, clickers are expected to increase students' participatory learning.

Students have more quality learning experience when the in-class activities are intellectually stimulating and challenging. With today's technologically savvy students, we believe that the implementation of clicker technology represents an example of discontinuous innovation in learning. Thereby, clickers, as a dynamic assessment tool, will provide students with positive attitudes toward learning and facilitate their critical thinking.

\section{REFERENCES}

Feurstein, Reuven. 1990. "The Theory of Structural Cognitive Modifiability.” In Learning and Thinking Styles: Classroom Application. Ed. B. Presseisen. Washington, DC: National Educational Association.

Vygotski, Lev. 1978. "Interaction Between Learning and Development." In Mind in Society: The Development of Higher Psychological Processes. Eds. M. Colem et. al. Cambridge, MA: Harvard University Press. 